\title{
Morphological and Functional Dimorphism in Xenorhabdus spp., Bacteria Symbiotically Associated with the Insect Pathogenic Nematodes Neoaplectana and Heterorhabditis
}

\author{
By R. J. AKHURST \\ Division of Entomology, CSIRO, Stowell Avenue, Hobart, Tasmania 7000, Australia
}

(Received 7 May 1980; revised 14 July 1980)

Xenorhabdus spp., entomopathogenic bacteria symbiotically associated with the nematodes Neoaplectana and Heterorhabditis, occur in two forms. In general, only one form, designated the primary form, is transmitted into new hosts by the infective stage of the nematode. The significance of the relationship between the two forms has been examined with $X$. nematophilus, the symbiont of $N$. feltiae. The forms of $X$. nematophilus can be differentiated by their colony characteristics but by only two biochemical tests. The two forms of $X$. nematophilus are equally pathogenic when injected into the haemocoel of Galleria larvae. However, the primary form when injected into Galleria larvae with axenic nematodes provides better conditions for reproduction of the nematodes than the secondary form, for which a role has not been determined. Although the primary form readily converts to the secondary form in vitro and occasionally in vivo, the secondary form is usually stable. Possible causes of the instability have been investigated.

\section{INTRODUCTION}

Three genera of insect pathogenic nematodes are known to have specific symbiotic associations with bacteria: Neoaplectana spp. and Heterorhabditis spp. are associated with Xenorhabdus spp. (Thomas \& Poinar, 1979) and Steinernema kraussei with a Flavobacterium sp. (Mrácek, 1977). Each species of nematode is associated with a single bacterial species; all Heterorhabditis spp. examined have Xenorhabdus luminescens as the symbiont but each species of Neoaplectana is associated with a different species of bacterium (R. J. Akhurst, unpublished results). The bacterial symbiont is carried monoxenically in the intestine of the non-feeding infective stage of the nematode. The nematode penetrates an insect host and moves to the haemocoel where it voids the bacteria. The bacteria proliferate, kill the host and establish suitable conditions for reproduction of the nematodes by providing nutrients and inhibiting the growth of other bacteria (Poinar \& Thomas, 1966). The symbiotic bacteria are also capable of rendering a wide variety of artificial media suitable for nematode reproduction, thus allowing the economical mass production of the nematodes (Bedding, 1976) necessary for the control of insect pests in the field.

During a study of the bacterial symbionts of many isolates of several species of Neoaplectana and Heterorhabditis from Australia, Europe, New Zealand and North America, I found that all may produce two forms of colony on agar media. The results of an investigation into the significance of and the relationships between the two forms of $X$. nematophilus, the symbiont of $N$. feltiae, are presented in this paper. 
Table 1. Nematodes from which bacteria were isolated for use in this study

\begin{tabular}{|c|c|c|c|}
\hline \multicolumn{2}{|c|}{ Nematode } & \multirow[b]{2}{*}{ Bacterium } & \multirow[b]{2}{*}{ Source } \\
\hline Species & Variety & & \\
\hline Neoaplectana feltiae & $\begin{array}{l}\text { Agriotos } \\
\text { Nelson } \\
\text { Pieridarum } \\
\text { P7 } \\
\text { N55 }\end{array}$ & $\begin{array}{l}\text { Xenorhabdus } \\
\text { nematophilus } \\
X . \text { nematophilus } \\
X . \text { nematophilus } \\
\\
X . \text { nematophilus } \\
X . \text { nematophilus }\end{array}$ & $\begin{array}{l}\text { G. O. Poinar, University of California, } \\
\text { Berkeley, U.S.A. } \\
\text { Vespula sp., Tasmania, Australia } \\
\text { S. Stanuszek, Institute of Ecology, } \\
\text { Warsaw, Poland } \\
\text { Soil*, Tasmania, Australia } \\
\text { Soil*, N.S.W., Australia }\end{array}$ \\
\hline N. bibionis & $\begin{array}{l}\text { NBP } \\
\text { NZ } \\
\text { V1 } \\
5 \text { isolates }\end{array}$ & $\begin{array}{l}\text { Xenorhabdus sp. } \\
\text { Xenorhabdus sp. } \\
\text { Xenorhabdus sp. } \\
\text { Xenorhabdus sp. }\end{array}$ & $\begin{array}{l}\text { Z. Mrácek, Entomological Institute, CSAV, } \\
\text { Ceské, Budejovice, Czechoslovakia } \\
\text { W. Wouts, DSIR, New Zealand } \\
\text { Soil*, Victoria, Australia } \\
\text { Soils*, Tasmania, Australia }\end{array}$ \\
\hline$N$. glaseri & 一 & Xenorhabdus sp. & $\begin{array}{l}\text { H. Kaya, University of California, } \\
\text { Davis, U.S.A. }\end{array}$ \\
\hline $\begin{array}{c}\text { Heterorhabditis } \\
\text { bacteriophora }\end{array}$ & - & $X$. luminescens & W. Wouts, DSIR, New Zealand \\
\hline H. heliothidis & $\begin{array}{l}\mathrm{NC} \\
\mathrm{NZ}\end{array}$ & $\begin{array}{l}X . \text { luminescens } \\
X . \text { luminescens }\end{array}$ & $\begin{array}{l}\text { W. Wouts, DSIR, New Zealand } \\
\text { W. Wouts, DSIR, New Zealand }\end{array}$ \\
\hline Heterorhabditis spp. & $\begin{array}{l}\text { D1 } \\
\text { HP } \\
\text { T280 } \\
\text { T301 }\end{array}$ & $\begin{array}{l}X . \text { luminescens } \\
X . \text { luminescens } \\
X . \text { luminescens } \\
X . \text { luminescens }\end{array}$ & $\begin{array}{l}\text { Soil*, Northern Territory, Australia } \\
\text { S. Stanuszek, Institute of Ecology, } \\
\text { Warsaw, Poland } \\
\text { Soil*, Tasmania, Australia } \\
\text { Soil*, Tasmania, Australia }\end{array}$ \\
\hline
\end{tabular}

\section{METHODS}

Isolation of bacteria. The symbiont of the DD136 strain of Neoaplectana feltiae (syn. carpocapsae, Stanuszek 1974) was obtained from the American Type Culture Collection (ATCC 19061). The other symbiotic bacteria used in this study were isolated, directly or indirectly, from the nematodes listed in Table 1.

Some symbiotic bacteria were isolated directly from the infective stage nematode. 'Infectives' (about 50) were surface-sterilized by immersion in $0.1 \%(\mathrm{w} / \mathrm{v})$ merthiolate (Eli Lilly \& Co., Indianapolis, U.S.A.) for 2 to $3 \mathrm{~h}$; after being washed three times in sterile water, they were suspended in YS broth $\left(\mathrm{NH}_{4} \mathrm{H}_{2} \mathrm{PO}_{4}\right.$, $0.5 \mathrm{~g} ; \mathrm{K}_{2} \mathrm{HPO}_{4}, 0.5 \mathrm{~g} ; \mathrm{MgSO}_{4} .7 \mathrm{H}_{2} \mathrm{O}, 0.2 \mathrm{~g} ; \mathrm{NaCl}, 5 \mathrm{~g}$; yeast extract, $5 \mathrm{~g}$; water, 1 1: Dye, 1968) and macerated in a tissue homogenizer. Samples of the macerate were spread on nutrient agar (NA) or nutrient agar with $0.004 \%(\mathrm{w} / \mathrm{v})$ triphenyltetrazolium chloride and $0.025 \%(\mathrm{w} / \mathrm{v})$ bromothymol blue (NBTA). Cultures of other symbiotic bacteria were obtained indirectly from the nematodes by sampling the haemocoel of Galleria mellonella (L.) larvae infected by nematodes or re-isolated from monoxenic cultures of nematodes and their symbiont on artificial media. These cultures were originally established with axenic nematodes obtained by the method of Poinar \& Thomas (1966) and pure cultures of the symbiont.

Except where otherwise specified, all cultures were incubated in the dark at $28^{\circ} \mathrm{C}$.

Differentiation of the forms. Both forms of $X$. nematophilus isolated from the Agriotos strain of $N$. feltiae were examined for differences in gross cell morphology and in reaction in biochemical and antibiotic sensitivity tests. The tests (Table 2) were carried out using standard methods although the phenylalanine deaminase test was conducted at 5 instead of $2 \mathrm{~d}$ and for the lipase test the Tween 80 concentration was reduced to $0.2 \%(w / v)$.

The pathogenicity of the two forms of the $N$. feltiae Agriotos symbiont was compared by estimation of $\mathrm{LD}_{50}$ following intrahaemocoelic injection of Galleria larvae. The concentration of cells in shaken, $24 \mathrm{~h}$ YS broth cultures was estimated by use of a counting slide. Each culture was then serially diluted with sterile Ringer's solution (Cruickshank et al., 1970) to give seven doses from approximately 0.05 to 50 cells $\mu 1^{-1}$. For each dose, 20 Galleria larvae were injected using a $10 \mu \mathrm{l}$ syringe with $0.5 \mathrm{~mm}$ diameter cannula. Another 20 larvae were injected with sterile Ringer's solution only. The larvae were incubated at $22^{\circ} \mathrm{C}$ on dry filter paper for $3 \mathrm{~d}$. $\mathrm{LD}_{50}$ was determined by probit analysis (Bliss, 1938). The $\mathrm{LD}_{50}$ values, transformed to logarithms, were compared by $t$-test. 


\section{Table 2. Tests used to compare the two forms of symbiotic bacteria}

Acetoin
Acid from carbohydrates*
Aesculin hydrolysis
Antibiotic sensitivity†
Bioluminescence
Casein hydrolysis
Catalase
Chitinase
Cultural characteristics
- nutrient agar
- MacConkey agar
- tergitol-7 agar
Triple sugar iron agar
Cytochrome oxidase
Decarboxylase - glutamic acid

Dihydrolase - arginine
DNAase - lysine

\author{
Gelatin hydrolysis \\ Indole \\ KCN \\ Lecithinase \\ Lipase \\ Maximum growth temperature \\ Methyl red \\ Motility \\ $\mathrm{NaCl}$ tolerance \\ Nitrate reduction \\ Oxidase \\ Oxidation - fermentation \\ Phenylalanine deaminase \\ Protease \\ Reducing substance from sucrose \\ Starch hydrolysis \\ Tyrosinase \\ Urease \\ Utilization of organic acids $\ddagger$
}

\section{* 30 carbohydrates tested. $\quad+15$ antibiotics tested. $\quad \ddagger 13$ organic acids tested.}

Effect of bacterial forms on nematode reproduction. The two forms of the $N$. feltiae Agriotos symbiont were cultured separately in YS broth shaken at $25{ }^{\circ} \mathrm{C}$ for $24 \mathrm{~h}$ and diluted with sterile Ringer's solution to about $10^{5}$ cells $\mathrm{ml}^{-1}$. Galleria larvae were injected with 10 axenic $N$. feltiae Agriotos infectives $24 \mathrm{~h}$ after injection of $10^{3}$ cells of one or other form of the symbiont (the interval between the injections avoiding the effect of the live insect host on nematode growth). The Galleria larvae were incubated at $22{ }^{\circ} \mathrm{C}$. After 5 and $8 \mathrm{~d}$ some of the larvae were dissected and the lengths of nematode females were measured, using an eyepiece micrometer. When nematode reproduction was completed, the remaining 20 Galleria cadavers were dissected in water and the number of nematodes was estimated by counting the nematodes in three samples taken from an agitated suspension.

Stability. The stability (i.e. the ability to resist change to the alternative form) of the forms was examined under a variety of conditions. Monoxenic cultures of nematodes and their symbionts on artificial media and cultures of either form of symbiont in peptone water and in YS broth, both shaken and stationary, were tested for a change of form over $30 \mathrm{~d}$ by streaking on NA or NBTA. Pure cultures of either form were also incubated, aerobically and anaerobically, on NA. These were subcultured three times at intervals of $3 \mathrm{~d}$, and at these times samples were streaked on to NBTA and incubated aerobically. Galleria infected by $N$. feltiae infectives while buried in sand, or injected with either form of the symbiont, with or without $N$. feltiae infectives, were also sampled. Each Galleria cadaver was dipped in ethanol, ignited and plunged into sterile Ringer's solution; the haemocoel was exposed and irrigated with the Ringer's solution. The liquid was serially diluted and $0.1 \mathrm{ml}$ samples were spread on NBTA. Infective nematodes, harvested from injected or naturally infected Galleria and stored in water from 1 to $90 \mathrm{~d}$, were macerated as before to determine the form of the symbiont carried.

Deep-freezing and freeze-drying were tested as methods of storing pure cultures of the forms over long periods. A loopful of bacteria from a $24 \mathrm{~h}$ YS agar culture was dispersed in $5 \mathrm{ml}$ nutrient broth containing $17 \%(\mathrm{v} / \mathrm{v})$ glycerol and immediately deep-frozen $\left(-18{ }^{\circ} \mathrm{C}\right)$. Such cultures were revived by rapid thawing in a $56{ }^{\circ} \mathrm{C}$ water bath and subculturing on YS agar or in YS broth. For freeze-drying, the bacteria were washed from $48 \mathrm{~h}$ YS broth cultures with $5 \%(\mathrm{w} / \mathrm{v})$ peptone $/ 3 \%(\mathrm{w} / \mathrm{v})$ sucrose and freeze-dried in a Dynavac FD16 high vacuum freeze-drying unit at $10^{-3}$ Torr (about $0 \cdot 1 \mathrm{~Pa}$ ) and $-70^{\circ} \mathrm{C}$.

Cause of form change. The symbiont of $N$. feltiae Agriotos was investigated to determine whether the change of form may have been mediated by bacteriophage or plasmid. The treatments used were u.v.irradiation, culture in the presence of a chemical curing agent (acridine orange, ethidium bromide, sodium dodecyl sulphate) and culture near the maximum temperature for growth.

\section{RESULTS}

All isolates of symbiotic bacteria from $N$. feltiae (6 strains), N. bibionis (9), N. glaseri (1), $H$. bacteriophora (1), H. heliothidis (2) and unidentified Heterorhabditis spp. (6) occurred in two forms. Infective stage nematodes contained only one of the forms, with the exception 
Table 3. Pathogenicity of primary and secondary forms of the symbiont of $N$. feltiae Agriotos following intrahaemocoelic injection of Galleria larvae

$\mathrm{LD}_{50}$ was determined by probit analysis and the values of $\log \mathrm{LD}_{50}$ were compared by a $t$-test.

$\begin{array}{lccc} & \text { Primary form } & \text { Secondary form } & \\ \mathrm{LD}_{50} & 3.0 & 2.0 & t=1.45 \text { (not significant) } \\ \text { S.E. } & 0.6 & 0.4 & \end{array}$

Table 4. Effect of primary and secondary form bacteria on the size and yield of $N$. feltiae following injection of bacteria and axenic infectives into Galleria larvae

Data on the length of adult females was analysed by analysis of variance and that on yield by a $t$-test.

\begin{tabular}{|c|c|}
\hline $\begin{array}{c}\text { Time after } \\
\text { injection of } \\
\text { nematodes (d) }\end{array}$ & Character \\
\hline 5 & $\begin{array}{l}\text { No. of females measured } \\
\text { Mean length (mm) } \\
\text { s.E. }\end{array}$ \\
\hline 8 & $\begin{array}{l}\text { No. of females measured } \\
\text { Mean length (mm) } \\
\text { S.E. }\end{array}$ \\
\hline 20 & $\begin{array}{l}\text { Estimated no. of infectives } \\
\text { produced from } 20 \\
\text { Galleria larvae }\end{array}$ \\
\hline
\end{tabular}

$\begin{array}{ccc}\overbrace{\text { Primary }}^{2} \text { Secondary } & P \\ 11 & 17 & \\ 12 \cdot 2 & 4 \cdot 1 & <0.01 \\ 1 \cdot 4 & 2 \cdot 0 & \\ 15 & 10 & \\ 11 \cdot 7 & 4 \cdot 9 & <0.001 \\ 0 \cdot 2 & 3.5 & \\ 2 \cdot 14 \times 10^{6} & 0.30 \times 10^{6} & <0.001 \\ & & \\ 0.02 \times 10^{6} & 0.013 \times 10^{8} & \end{array}$

of the NZ strain of $H$. heliothidis and under some experimental conditions. This form was designated primary and the other secondary. The secondary form occurred, with the primary form, in monoxenic cultures initiated with the primary form and occasionally in the haemocoel of infected Galleria larvae. Infective stage nematodes only carried secondary form bacteria when the nematodes were produced in the absence of the primary form.

\section{Differentiation of the forms}

On NA, colonies of the primary form of $X$. nematophilus, the $N$. feltiae symbiont, were white, opaque, convex and circular with an irregular margin; colonies of the secondary form were translucent, flatter and of greater diameter than the primary form. The difference in the colonies showed up more clearly on agars containing bromothymol blue and triphenyltetrazolium chloride (TTC), e.g. NBTA. On these agars, the primary form absorbed bromothymol blue and reduced TTC, producing colonies which had a red core overlaid by dark blue and were surrounded after 3 to $5 \mathrm{~d}$ by a clear zone; the secondary form reduced TTC but did not absorb bromothymol blue and so produced red colonies, which sometimes appeared maroon because of the blue agar, with no clear zone.

Xenorhabdus nematophilus produced some colonies that were intermediate between the two forms. On NBTA these had segments of blue and red, or were maroon rather than blue or red. Pure cultures of either form could rarely be obtained by subculturing from these intermediate colonies.

The two forms of the $N$. feltiae Agriotos symbiont did not differ in antibiotic resistance or reaction in most biochemical tests. However, the primary form of this bacterium gave negative results for phenylalanine deaminase and lipase activity while the secondary form was positive. When samples of cultures containing both forms of the $N$. feltiae Agriotos symbiont were spread on NA, NBTA and tergitol-7 plus TTC, the highest proportion of colonies of the secondary form were on NA and the lowest on tergitol-7 plus TTC. 


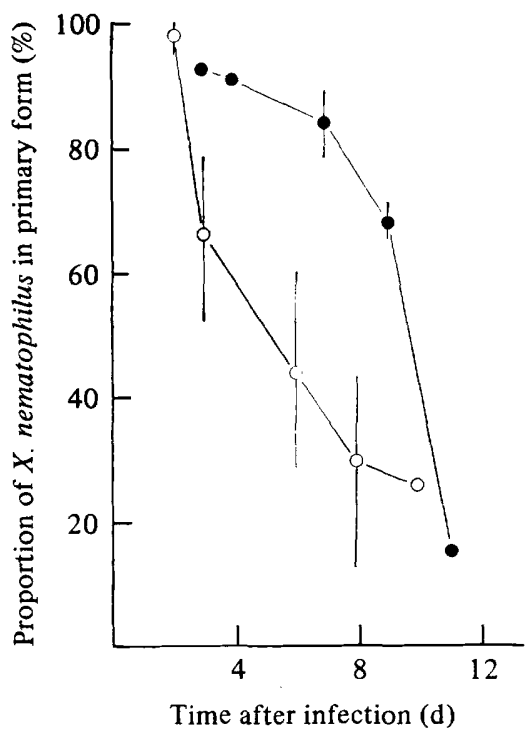

Fig. 1. Proportion of $X$. nematophilus in the primary form in Galleria larvae incubated at $22{ }^{\circ} \mathrm{C}$ after natural infection by Agriotos $(O)$ and Nelson (O) strains of $N$. feltiae. Two larvae were sampled at each time; serial dilutions of dissected larvae were spread on NA, incubated at $28^{\circ} \mathrm{C}$ and assessed after 4 to $6 \mathrm{~d}$. Experiments were terminated when the recovery of $X$. nematophilus from the larvae was too low to give a realistic estimate of the proportion of $X$. nematophilus in the primary form. For both the Agriotos and Nelson varieties, the estimate of proportion at the last sampling was based on the result from one cadaver only. Mean and s.E. were calculated on arcsin $\sqrt{ }$ percentage transformed data. Vertical lines represent S.E.

There was no significant difference in the pathogenicity of the primary and secondary forms of the N. feltiae Agriotos symbiont (Table 3).

\section{Effects of bacterial forms on nematode reproduction}

The effects of primary and secondary form bacteria on the size of adult female $N$. feltiae Agriotos in Galleria injected with axenic infectives and either form of the bacterium are shown in Table 4 . In each case the difference between the primary and secondary forms was highly significant.

The nematodes matured and reproduced more quickly in the presence of the primary form. The yield from Galleria injected with primary form $X$. nematophilus and axenic infectives was greater than from Galleria injected with secondary form and axenic infectives (Table 4).

\section{Stability}

The primary form of $X$. nematophilus was unstable but the degree of instability was very variable. The symbionts of the Agriotos and Nelson strains of $N$. feltiae converted from primary to secondary form much more readily than those of the DD136 and Pieridarum strains.

Pure cultures of the primary form of all isolates of $X$. nematophilus could be maintained by freeze-drying, deep-freezing or by frequent subculture. However, when broth cultures, shaken or stationary, and cultures on agar media incubated at $28^{\circ} \mathrm{C}$ for more than $7 \mathrm{~d}$ were subcultured, some colonies of the secondary form were evident. In vitro monoxenic cultures of nematodes and primary form bacteria also produced the secondary form, though sometimes not for several weeks and after several subcultures. The primary form of most isolates was stable in Galleria larvae, whether or not nematodes were present. However, the 
primary form of the symbionts of the Agriotos and Nelson strains of $N$. feltiae, though stable if nematodes were absent, was unstable in cadavers in the presence of nematodes (Fig. 1).

The secondary form of the $N$. feltiae symbiont was stable on agar media incubated aerobically, in monoxenic culture with nematodes and in Galleria, with or without nematodes. However, it was unstable in unshaken broth media and in anaerobic culture on NA. Infective nematodes harvested from Galleria injected with axenic $N$. feltiae Agriotos and secondary form bacteria contained only stable secondary form bacteria.

\section{Cause of form change}

There was no evidence for the involvement of bacteriophage or plasmid in mediating the change from one form to the other.

\section{DISCUSSION}

The existence of two forms of each bacterial species symbiotically associated with the insect pathogenic nematodes Neoaplectana and Heterorhabditis is undoubtedly significant as all such bacteria examined exhibit this phenomenon, as does the Flavobacterium sp. symbiont of a similar nematode, Steinernema kraussei (R. J. Akhurst, unpublished results). In N. feltiae (and other species of Neoaplectana and Heterorhabditis; R. J. Akhurst, unpublished results) the primary form is preferentially retained in the intestine of the infective stage of the nematode, allows faster and significantly greater reproduction by the nematodes, and is less stable than the secondary form. It is therefore difficult to envisage the role of the secondary form. This form may be the original symbiont from which has developed another, unstable, form that better suits the nematodes' requirements and has gained a selective advantage in being retained preferentially by the infective stage. The secondary form certainly has significance in in vitro monoxenic culture of the nematodes, where it is detrimental to the final yield.

Infective $N$. feltiae produced in insects or in vitro culture in the presence of both forms of $X$. nematophilus contain only the primary form, even though the proportion of $X$. nematophilus in the primary form within the insect or culture may be only $20 \%$. However, these nematodes are capable of carrying the secondary form internally as this occurs when infectives are produced where only the secondary form is present. The mechanism which ensures that infective $N$. feltiae preferentially carry the primary form, which is superior for their reproductive requirements, without losing the capacity to carry the secondary form, has not been determined. This mechanism must operate within the nematode, either during the feeding, pre-infective stages or the non-feeding infective stage, since there is no transmission of bacteria through the egg (R. J. Akhurst, unpublished results).

Only the symbionts of the Agriotos and Nelson strains of $N$. feltiae produced the secondary form when introduced into Galleria larvae with axenic nematodes and these differed in the rate at which the secondary form was produced (Fig. 1). It appears that different isolates of Xenorhabdus exhibit different levels of stability with the symbiont of $N$. feltiae Agriotos being the most unstable of those examined.

In characterizing the genus Xenorhabdus, Thomas \& Poinar (1979) have apparently used only primary form bacteria, though the cultures of $\mathrm{Hb}, \mathrm{Hb}-\mathrm{M}$ and $\mathrm{Hm}$ may have contained some secondary form bacteria. The characterization of the genus may need to be amended to allow for the inability of the secondary form colonies to absorb bromothymol blue and that of the species $X$. nematophilus to allow for the lipase and phenylalanine deaminase activity of the secondary form.

Neoaplectana feltiae Agriotos produced 7 times as many infectives from Galleria larvae when the primary, rather than secondary, form was injected into the insects with axenic infectives. R. A. Bedding (personal communication) found that mass cultures of $N$. feltiae Agriotos and $H$. heliothidis NZ with the primary form of their symbionts yielded 1.6 and 2.9 times, respectively, as many nematodes as cultures with the secondary form. The 
difference in the ratio for $N$. feltiae Agriotos in Galleria and in monoxenic cultures is probably due to the contamination by the secondary form of monoxenic cultures of nematode and primary form (and vice versa) that is unavoidable when Bedding's method is used (unpublished results).

Apart from the obvious biological interest of this phenomenon, dimorphism in Xenorhabdus spp. is of considerable practical importance in the mass production of Neoaplectana and Heterorhabditis for pest insect treatment.

I would like to thank Dr R. A. Bedding and Dr M. A. Line for discussions on this study and, with Mr K. L. Taylor, for criticism of the manuscript. The technical assistance of Messrs V. Patel, J. Moss and M. Stanfield is appreciated.

\section{REFERENCES}

BedDing, R. A. (1976). New methods increase the feasibility of using Neoaplectana spp. (Nematoda) for the control of insect pests. Proceedings of the First International Colloquium on Invertebrate Pathology, Kingston, Canada, pp. 250-254.

Bedding, R. A. \& AkHurst, R. J. (1975). A simple technique for the detection of insect parasitic rhabditid nematodes in soil. Nematologica 21, 109-110.

BLIss, C. I. (1938). The determination of the dosagemortality curve from small numbers. Quarterly Journal of Pharmacy and Pharmacology 11, 192-216.

Cruickshank, R., Duguid, J. P. \& Swain, R. H. A. (editors) (1970). Medical Microbiology, 11th edn. Edinburgh: E. \& S. Livingstone.

DYE, D. W. (1968). A taxonomic study of the genus Erwinia I. The 'amylovora' group. New Zealand Journal of Science 11, 590-607.

MRÁCEK, Z.. (1977). Steinernema kraussei, a parasite of the body cavity of the sawfly, Cephalia abietis, in Czechoslovakia. Journal of Invertebrate Patho$\log y$ 30, 87-94.

PoINar, G. O. \& Thomas, G. M. (1966). Significance of Achromobacter nematophilus Poinar \& Thomas (Achromobacteriaceae: Eubacteriales) in the development of the nematode, DD136 (Neoaplectana sp. Steinernematidae). Parasitology 56, 385390.

Stanuszek, S. (1974). Neoaplectana feltiae Pieridarum n. ecotype (Nematoda: Rhabditidea, Steinernematidae) - a parasite of Pieris brassicae L. and Mamestra brassicae L. in Poland. Morphology and biology. Zeszyty problemowe postepow nauk rolniczych 154, 361-393.

Thomas, G. M. \& Polnar, G. O. (1979). Xenorhabdus gen. nov., a genus of entomopathogenic, nematophilic bacteria of the family Enterobacteriaceae. International Journal of Systematic Bacteriology 29, 352-360. 